Annals of Plant and Soil Research 23(3): 238-255 (2021)

https://doi.org/10.47815/apsr.2021.10067

\title{
Nanofertilizers and their role in sustainable agriculture
}

\author{
YOGENDRA KUMAR ${ }^{1}$, K.N. TIWARI ${ }^{2}$ TARUNENDU SINGH $^{1}$ AND RAMESH RALIYA ${ }^{3}$ \\ Indian Farmers Fertiliser Cooperative Limited, IFFCO Sadan, C-1, District Centre, Saket Place, New \\ Delhi -110017
}

Received: April, 2021: Revised accepted: June, 2021

\begin{abstract}
Enhancing nutrient use efficiency (NUE) with minimal threat to environment has become critical for our agriculture food production systems (FPS) to sustain the burgeoning population. Nanotechnology with nanoscale inputs for production of nano agri-inputs (NAIPs) has emerged as an innovative solution for addressing issue of low or declining nutrient use efficiency (NUE) with minimal environment footprint. Nanotechnology is a promising field of research which has the potential to offer sustainable solutions to ever pressing challenges confronting our modern intensive agriculture. Nanotechnology employs nanomaterials which typically have small size $(1-100 \mathrm{~nm})$ which imparts unique characteristics and benefits. In addition to numerous other benefits, large surface area to volume ratio offers opportunity for better and effective interaction of nanoparticles to target sites. Nano-fertilizers hold potential to fulfil plant nutrition requirements along with imparting sustainability to crop production systems and that too without compromising the crops yield. Indian Farmers Fertilizer Cooperative Limited (IFFCO) - the farmers' own fertilizer cooperative has been in the forefront for promotion of agro-technologies and novel agri-inputs to mitigate problems faced by the farmers. It has indigenously innovated at its Nano Biotechnology Research Centre (NBRC) at Kalol, Gujarat and succeeded in $R \& D$ and manufacturing of proprietary nano-fertilizers viz. nano urea, nano zinc, and nano copper. These nano-fertilizers utilize the dynamics of shape, size, surface area and bio-assimilation. There efficacy was evaluated on the basis of multi-location multi-crop trials under varying crop seasons, both by the research institutes and also on the progressive farmers' fields across 11,000 locations on 94 crops across India. Independently, nano nitrogen, nano zinc, and nano copper have also been tested for bio-efficacybio safety- toxicity and environment suitability. IFFCO nano-fertilizers meet alll the current national and international guidelines related to nano technology or nano scale agri-inputs. They are in sync with OECD testing guidelines (TGs) and "Guidelines for Testing of NAIPs and Food Products" released by the Department of Biotechnology, Government of India. Harvested produce of crops applied with IFFCO nano-Urea, nano-zinc, and nano-copper have been found fit for consumption with no adverse effect. This paper reviews the benefits of nanofertilizers (Nano N, Nano $\mathrm{Zn}$ and Nano $\mathrm{Cu}$ ) towards increasing nutrient use efficiency and crop productivity and produce quality in general and the journey of IFFCO nano-fertilizers (IFFCO's Nano Urea, Nano Zn and Nano $\mathrm{Cu}$ ) from conception to PILOT to PLANT stage has also been covered in this paper.
\end{abstract}

Key Words: Nutrient use efficiency, Nanofertilizers, Nano-N, Nano-Zn, Nano-Cu, IFFCO's Nano Urea, IFFCO's Nano-Zn, IFFCO's Nano-Cu, Crop response to Nanoferilizers, Sustainable agriculture

\section{INTRODUCTION}

Since green revolution, chemical fertilizers are deemed an indispensable input of modern crop production systems, but these have associated environmental and ecological consequences. Loss of nutrients from agricultural fields in the form of leaching and gaseous emissions has been the leading cause of environmental pollution and climate change. Intensive farming practices introduced and evolved since the inception of green revolution have been deemed unsustainable as the utilization efficacy of applied chemicals including mineral fertilizers has remained below $30 \%$. Fertilizers have taken axial role with respect to boosting crops yield and nutritional quality especially after the development of fertilizer responsive crop varieties. Among mineral nutrients, nitrogen is the first and foremost nutrient required for crop plants as it is the constituent of chlorophyll and many proteins and enzymes and thus plays a significant role during the vegetative growth of crops. Nitrogen is absorbed by the plants in the form of nitrate $\left(\mathrm{NO}_{3}^{-}\right)$and ammonium $\left(\mathrm{NH}^{+}{ }_{4}\right)$. Nitrogen is lost through the processes of nitrate leaching, denitrification and ammonia volatilization. Loss of mineral nutrients through leaching and runoff to surface and ground water along with abundant volatilization constitute growing concerns owing to economic losses and environmental pollution. 
Conventional application techniques are resulting in seriously overdosing of chemical fertilizers which has become evident through the phenomenon of eutrophication (algal growth on the surface of water bodies due to nutrients enriched water, which hampers oxygen supply to fish). Moreover, nitrogen volatilization results in the release of nitrous oxides and thus being the greenhouse gases, contribute to the global warming. It is also pertinent to mention that ammonium ions react with alkaline rain water which leads to the formation of ammonia gas that escapes into the atmosphere and thus becoming a source of environmental pollution. Whenever, there is excess of nitrogen, more and more nitrates and ammonium ions get accumulated in the leaves of crops especially leafy vegetables and become detrimental to human health. In addition, nitrate rich diets have been reported to be associated with numerous human diseases such as bladder and gastric cancer as well as methemoglobinemia. It is being stressed to deliver the required quantities of active agents only where they are direly needed. Environmentalists and consumers call for reducing the use of synthetic fertilizers to decrease pollution and residue effect on form produces along with conserving agroecosystems. It is really unfortunate that modern profit-oriented farming systems have become unstable mainly due to poor nutrient use efficiency and imbalanced excessive fertilizer application.

Ensuring the sustainability of crop production necessitates exploring other sources of nutrients and modifying prevalent nutrient sources. Nanotechnology, which utilizes nanomaterials of less than $100 \mathrm{~nm}$ size, may offer an unprecedented opportunity to develop concentrated sources of plant nutrients having higher-absorption rate, utilization efficacy, and minimum losses. Nano-fertilizers are being prepared by encapsulating plant nutrients into nanomaterials, employing thin coating of nanomaterials on plant nutrients, and delivering in the form of nano-sized emulsions. Nano-pores and stomatal openings in plant leaves facilitate nanomaterial uptake and their penetration deep inside leaves leading to higher nutrient use efficiency (NUE). Nanofertilizers have higher transport and delivery of nutrients through plasmodesmata, which are nanosized (50$60 \mathrm{~nm}$ ) channels between cells. The higher NUE and significantly lesser nutrient losses of nanofertilizers lead to higher productivity (6$17 \%$ ) and nutritional quality of field crops. However, production and availability, their sufficient effective legislation, and associated risk management are the prime limiting factors in their general adoption as plant nutrient sources. IFFCO has successfully innovated and achieved the goal of development and manufacturing of Nano Urea, Nano Zinc and Nano Copper as proprietary nano inputs through its indigenous R\&D efforts at Nano Biotechnology Research Centre (NBRC) Kalol, Gujarat. These nanoscale products utilise the benefit of dynamics of shape, size, surface area and bio assimilation. Nano fertilizers were evaluated through multilocation, multi-crop on-station trials in different seasons, by the research organizations and 11,000 onfarm trials conducted on progressive farmers' fields covering 94 crops across the country during 2019-20. This paper reviews the benefits of nanofertilizers (Nano N, Nano Zn and Nano $\mathrm{Cu}$ towards increasing nutrient use efficiency and crop productivity and produce quality in general and of IFFCO's Nano-Urea, Nano-Zn and Nano $\mathrm{Cu}$ in particular.

\section{SCENARIO OF FERTILIZER CONSUMPTION; DECLINING NUTRIENT USE EFFICIENCY AND INCREASING MULTI-NUTRIENT DEFICIENCIES}

In India, there is a little scope of bringing in more area under cultivation; therefore, growth in food grain production has to come largely through productivity enhancement. Food grain productivity has registered a phenomenal increase from $522 \mathrm{~kg}$ $\mathrm{ha}^{-1}$ in $1950-51$ to $2,235 \mathrm{~kg} \mathrm{ha}^{-1}$ in $2017-18$ but the decline in factor productivity of fertilizers in respect of food grain production indicates nutrient depletion in soil pool and reduction in NUE. This has resulted into decrease in crop response to application of plant nutrients from $15 \mathrm{~kg}$ food grain $\mathrm{kg}^{-1} \mathrm{NPK}$ during $5^{\text {th }}$ plan (1974-79) to less than $6 \mathrm{~kg}$ food grain $\mathrm{kg}^{-1}$ NPK in $11^{\text {th }}$ plan (2007-12) (Prasad 2013) which has further reduced to 2.7 food grain $/ \mathrm{kg}$ NPK in irrigated cropping systems (Figure 1). Alternatively, fertilizer use efficiency (FUE) which is dependent on several factors including nutrient uptake efficiency and soil health, determines our agricultural and 
environmental stability. Innovative fertilizers can fulfil the $4 \mathrm{R}$ principles effectively to address issue of declining FUE.

Fertilizer consumption in India is imbalanced, skewed in favour of urea-N. Resultantly, the NPK consumption ratio has widened from 4:3.2:1 in 2009-10 to 7.0:2.8:1 in 2019-20. Nitrogen application has spiked postNBS- 2010 after a brief correction. Nitrogen application has to be balanced in higher application regions and increased in the lower application regions. Among secondary and micronutrients, widespread deficiencies of sulphur (S), $\mathrm{Zn}$ and $\mathrm{B}$ have been recorded in cereals, pulses and oilseed

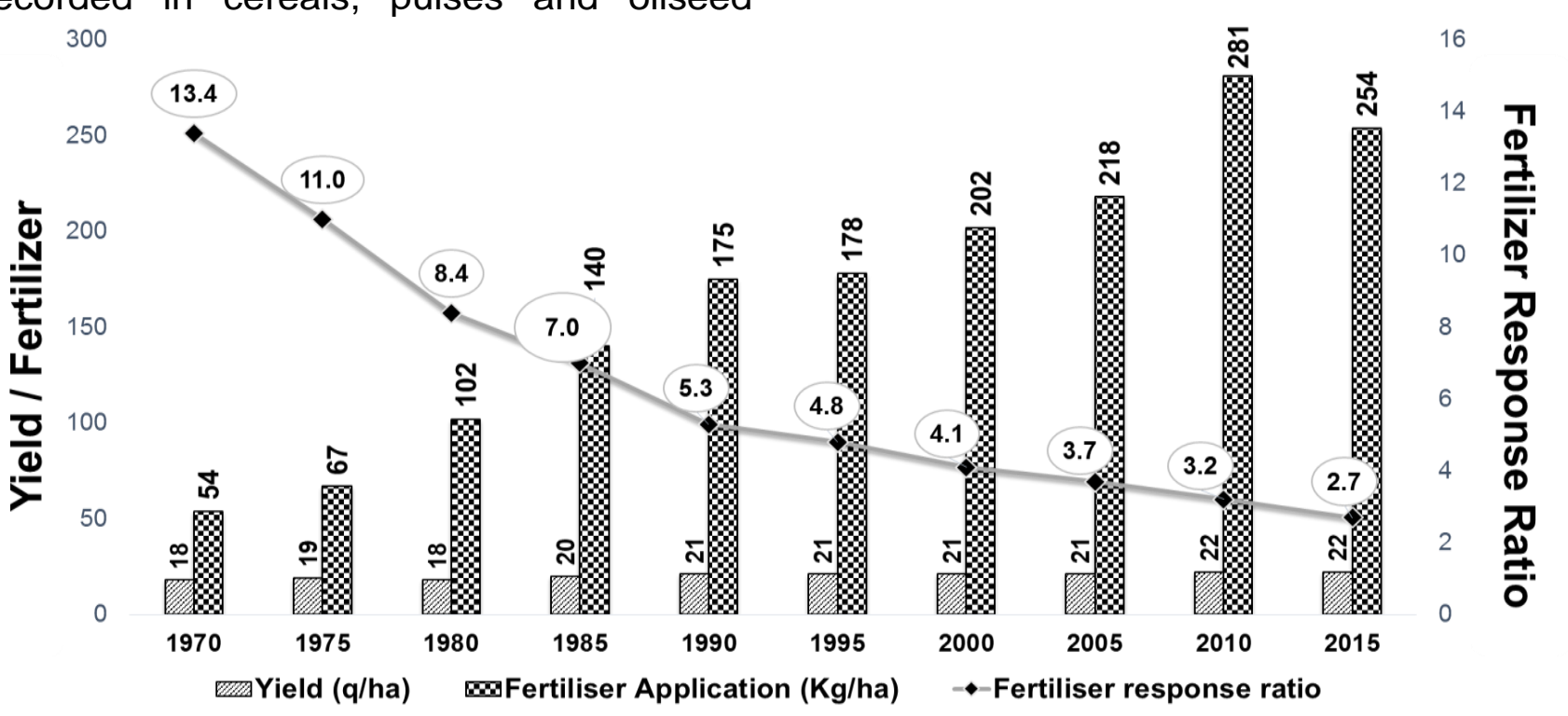

Figure 1: Increasing Food grain Production Decreasing Fertiliser Response ratio

\section{Injudicious Application of Urea-Matter of Growing Concern}

Imbalanced and injudicious application of urea is a matter of grave concern. Farmers have been called upontoreduceureaconsumptionbyatleast25 \%for better environmental quality and their own profitability. This issue needs to be crops in India. Copper deficiency has been observed in fruit crops. This suggests that the block-specific micronutrient deficiencies have to be delineated and ameliorated for better crop productivity and farmers' profitability. Bio fortification of micronutrients in crops will address human and animal micronutrient deficiencies too. Only enhanced NUE of major and micronutrients with better soil health and agronomic management practices can meet the challenges, being currently faced by the farmers, researchers and policy makers.

Table 1: Urea Production, Import and Consumption during last 5 Years (in ‘000 MT)

\begin{tabular}{|c|c|c|c|c|c|}
\hline \multirow{2}{*}{ Year } & \multirow{2}{*}{ Production } & \multirow{2}{*}{ Import } & \multicolumn{2}{|c|}{ Urea Consumption } & \multirow{2}{*}{ Total } \\
\cline { 4 - 5 } $2016-17$ & 24201 & 4971 & 14356 & Rabi & \\
$2017-18$ & 24023 & 6011 & 14832 & 15062 & 29614 \\
$2018-19$ & 23899 & 7555 & 15448 & 16571 & 29894 \\
$2019-20$ & 24455 & 9124 & 15369 & 18326 & 32019 \\
$2020-21$ & 24603 & 9828 & 17782 & 17260 & 33695 \\
\hline
\end{tabular}

agriculture in the light of sustainability of whole production systems and biogeochemical cycles. Urea accounts for $>82 \%$ of the nitrogenous fertilizers applied to majorityofthecropsinIndia.Around33million tones (Mt) urea is applied to various crops every year. Its consumption has reached to $35 \mathrm{Mt}$ during 2020-21 (Table 1). 
There has been a commensurate increase in production, import and consumption of urea over consecutive years. Import of urea has increased over the years, reaching a figure of $9.12 \mathrm{Mt}$ during 2019-20 and 9.82 Mt during 2020-21.Subsidy burden on account of urea import constitutes $26 \%$ of the overall urea subsidy paid in a year by Government of India (Table 2). Arresting increasing urea consumption through its judicious application, R\&D efforts, introduction of innovative products and contemporary policy measures is hence required. Nanofertilizers will play an important role to arrest increasing demand of urea, help reducing the import of urea and subsidy burden by way of increasing the nitrogen use efficiency.

Table 2: Subsidy paid by Government of India for Urea during last 3 years (Rs. Crore)

\begin{tabular}{|cc|c|c|}
\hline Year & Indigenous Urea & Imported Urea & Total \\
\hline $2016-17$ & 40000 & 11257 & 51257 \\
$2017-18$ & 36974 & 9980 & 46954 \\
$2019-20$ & 32190 & 17155 & 49345 \\
\hline
\end{tabular}

Note: 1 crore $=10$ million

\section{INNOVATIVE FERTILIZERS - KEY TO SUSTAINABILITY}

Novel and innovative fertilizer sapart from enhanced nutrient uptake efficiency offer benefits in terms of reduction in environment footprints. Fertilizer industry has pioneered and introduced enhanced efficiency fertilizers (EEF) which catertoaniche market only. For highly subsidized Indian fertilizer market, an innovative high-tech fertilizer which is economically affordable too can be a real solution. Nanotechnology can be leveraged to develop agricultural intensification solutions, which can increase food production per unit of inputs and resources. Nano fertilizers based on nanotechnology because of their size advantage and controlled manufacturing process through chemical, physical and biological means have emerged as a viable option to fulfill this gap in conventional and innovative fertilizer market.

\section{Nano fertilizers: Definition and Characteristics}

Nano-fertilizers by definition are, "Synthesized or modified form of traditional fertilizers, fertilizer bulk materials or extracts of different botanical, microbial or animal origin manufactured by chemical, physical, mechanical or biological methods with the help of nanotechnology but not limited to it". These nanoparticles can also be made from bulk conventional fertilizers. At nano scale, physical and chemical properties of nanofertilizers are dynamic and different from their counterpart. Due to higher surface area to volume size ratio and nano size, they have high availability and absorption. Particle size of nano-fertilizers is less than 1-100 nm in at least one dimension which facilitates better uptake from soil or leaves, resulting in production of more photosynthates and biomass required for healthy crops. Nano-fertilizers have benefits in terms of application and small requirement, slow release mechanism, reduction in transportation and application cost, and cause comparatively low salt accumulation in soil vis-à-vis conventional fertilizers. These effectively meet crop nutrient requirement with increased bioavailability of nutrients. Foliar applied nano- fertilizers increase NUE and nutritional quality of crops through biofortification.

\section{ROLES OF NANOFERTILIZERS}

Agriculture in the twenty-first century is facing manifold challenges for producing more food by addressing the problems of rapidly growing global population, unpredictable climate change, decreasing agricultural productivity, variable labor force, and increased urbanization. The use efficiency of nutrients of traditional fertilizers is abysmally low. It has been reported that around $40-70 \%$ of nitrogen, $80-90 \%$ of phosphorus, and $50-90 \%$ of potassium content of applied fertilizers are lost in the environment and could not reach the plant which causes significant economic losses (Trenkel 2010; Saigusa 2000; Solanki et al. 2015). These problems seem to intensify fiercely by 2050 when we have to feed the population of over 9 billion. Agriculture as a source of food, feed and 
fiber has always been increasingly important in a world of diminishing resources and with an everincreasing global population (Brennan 2012). To counteract this scenario, the agriculturedependent countries have to adopt more advanced technologies, labor-saving practices, and methods. Nanotechnology is a promising tool and has the potential to foster a new era of precise farming techniques and therefore may emerge as a possible solution for these problems. Nanotechnology may increase agricultural potential to harvest higher yields in an eco-friendly way even in the challenging environments (Sugunan and Dutta 2008). Although the use of NPs in crop improvement is still under investigation, we can expect to see its use on a regular basis in farmers' fields in the near future.

The nanofertilizers release the nutrients in a controlled manner in response to the reaction to different signals such as heat, moisture, and other abiotic stress. Nanofertilizer may regulate the release of nutrients and deliver the correct quantity of nutrients required by the crops in suitable proportion and promote productivity while ensuring environmental safety (De Rosa et al. 2010). Millán et al. (2008) stated that $\mathrm{NH}^{+}$occupying the internal channels of zeolite may be released slowly and freely, thereby allowing the progressive absorption by the crop which is reflected in higher dry matter production of the crop. During the past few years, there has been extensive interest in applying NPs to plants for agricultural management (Nanotechnology in Agriculture and Food 2006; Torney et al. 2007; Khodakovskaya et al. 2009, 2012; Ashrafi et al. 2010; Serag et al. 2011b, 2012a; Husen and Siddiqi 2014; Razzaq et al. 2016). The genetic implications of such NP-induced positive changes have been validated through investigations on enhanced mRNA expression and protein level in spinach (Gao et al. 2008) by nano-TiO2, generational transmission of fullerol through seeds in rice (Lin et al. 2009), and changes in gene expression at plant and cellular levels in tomato and tobacco (Khodakovskaya et al. 2009, 2012; Villagarcia et al. 2012) by MWCNTs.

Dwairi (1998) suggested that zeolite impregnated with urea can be used as slowrelease fertilizer carrying the slow and steady release of $\mathrm{N}$ from nanozeolite. Perrin et al.(1998) demonstrated that amending sandy soil with ammonium-loaded zeolite can reduce $\mathrm{N}$ leaching while sustaining growth of sweet corn and increasing $\mathrm{N}$ use efficiency compared to ammonium sulfate. The same result was also demonstrated by Hernandez et al. (1994) that the combination of zeolite and slow-release $\mathrm{N}$ fertilizers would increase the $\mathrm{N}$ efficiency. Rahale (2010) reported that nanofertilizer increased the NUE up to $45 \%$ over control. She also reported that the release of nitrate from nanozeolite continued even after $1176 \mathrm{hrs}$, with concentrations ranging from 110 to $114 \mathrm{mmol}$ $\mathrm{L}^{-1}$. The results clearly demonstrated slow and steady release of $\mathrm{N}$ from nanozeolite for more than 45 days while conventional fertilizer does it for only 8 days.

We know that crops secrete carbonaceous compounds into the rhizosphere under nutrient stress that can consider as environmental signals for incorporation into novel nanofertilizers (Sultan et al. 2009). Novel nanofertilizer application has an edge over traditional methods of fertilizer application by releasing nutrients in a controlled manner, preventing eutrophication and pollution of water resources (Sekhon 2014; Naderi and Abedi 2012). The use of nanofertilizer not only causes increased use efficiency of the elements but also reduces the toxicity generated due to overapplication in the soil as well as reduces the split application of fertilizers (Naderi and DaneshShahraki 2013). The positive effect of the application of zinc oxide nanoparticles on tomato plants opens an avenue for its potential use as a future nanofertilizer. It has been observed that NPs in low concentrations have not displayed any harmful effect to plants but instead are capable of activating specific physiological and molecular responses. For example, $\mathrm{TiO} 2$ nanoparticles $(0.25-4 \%)$ are able to promote photosynthesis and nitrogen metabolism in spinach and, therefore, improve the growth of the plants (Zheng et al. 2005; Klaine et al. 2008). Khodakovskaya et al. (2009) demonstrated that relatively low doses $(10-40 \mu \mathrm{g} / \mathrm{mL})$ of multiwalled carbon nanotubes (MWCNTs) were able to penetrate thick seed coats, increase germination, and stimulate growth in tomato plants (Khodakovskaya et al. 2009, 2012). However, the effects of NPs are influenced by the media and the mode of application. Zhu et al. (2008) studied the uptake of 20-nm-sized iron 
oxide NPs $\left(\mathrm{Fe}_{3} \mathrm{O}_{4} \mathrm{NPs}\right)$ in pumpkin and lima beans (Phaseolus lunatus). Under hydroponic conditions, indications of magnetic NPs were found in roots, stems, and leaves, while the plants growing in soil or in sand did not show any signs of magnetic NPs confirming no particle uptake.

\section{Nano nitrogen}

To improve the nutrient use efficiency, nano-based slow-release or controlled-release fertilizers have the tremendous potential. Nanofertilizer may regulate the release of nutrients and deliver the correct quantity of nutrients required by the crops in suitable proportion and promote productivity while ensuring environmental safety (De Rosa et al. 2010). Millán et al. (2008) stated that NH4+ occupying the internal channels of zeolite may be released slowly and freely, thereby allowing the progressive absorption by the crop which is reflected in higher dry matter production of the crop. Dwairi (1998) suggested that zeolite impregnated with urea can be used as slowrelease fertilizer carrying the slow and steady release of $\mathrm{N}$ from nanozeolite. Perrin et al. (1998) demonstrated that amending sandy soil with ammonium-loaded zeolite can reduce $\mathrm{N}$ leaching while sustaining growth of sweet corn and increasing $\mathrm{N}$ use efficiency compared to ammonium sulfate. The same result was also demonstrated by Hernandez et al. (1994) that the combination of zeolite and slow-release $\mathrm{N}$ fertilizers would increase the $\mathrm{N}$ efficiency. Rahale (2010) reported that nanofertilizer increased the NUE up to $45 \%$ over control. She also reported that the release of nitrate from nanozeolite continued even after $1176 \mathrm{hrs}$, with concentrations ranging from 110 to $114 \mathrm{mmol}$ $\mathrm{L}^{-1}$. The results clearly demonstrated slow and steady release of $\mathrm{N}$ from nanozeolite for more than 45 days while conventional fertilizer does it for only 8 days.

In arid soil, it was observed that the engineered nanoparticles may be successfully utilized for mitigating the acute problem of moisture retention. Apart from moisture retention, nano-based slow-release fertilizers may augment crop production by mobilizing nutrients in the rhizosphere (Raliya et al. 2013). Nitrogen fertilizer fortified with nanoporous zeolite could be used as an alternative strategy to improve the nitrogen use efficiency in crop production systems (Manikandan and Subramanian 2014). It was observed an improved root development and shoot establishment in rice seedlings grown in carbon nanomaterial-enriched medium compared with the control seedlings by Nair et al. (2012). In an interesting study, Subramanian and Rahale (2009) have monitored the nutrient release pattern of nanofertilizer formulations carrying fertilizer nitrogen. The data have shown the nanoclay-based fertilizer formulations (zeolite and montmorillonite with a dimension of $30-40$ $\mathrm{nm})$ are capable of releasing the nutrients for a longer period of time $(>1000 \mathrm{~h})$ than conventional fertilizers ( $<500 \mathrm{~h})$. Kottegodaet al. (2011) in an interesting study, reported a sustained release of nitrogen into the soil using urea-modified hydroxyapatite nanoparticle which were encapsulated under pressure into cavities of the soft wood of Gliricidiasepium. In this study, the release of nitrogen from nanofertilizer followed a sequence of a two-step process: an initial burst and a subsequent slow release up to 60 days. Such release process has an edge over conventional commercial fertilizer, which released heavily at the beginning followed by low and nonuniform quantities until around 30 days. Subramanian and Rahale (2009) have monitored the nutrient release pattern of nanofertilizer formulations carrying fertilizer nitrogen. The data have shown the nanoclay-based fertilizer formulations (zeolite and montmorillonite with a dimension of $30-40 \mathrm{~nm}$ ) are capable of releasing the nutrients for a longer period of time $(>1000$ hrs) than conventional fertilizers ( $<500 \mathrm{hrs})$. The use of nanofertilizer not only causes increased use efficiency of the elements but also reduces the toxicity generated due to over-application in the soil as well as reduces the split application of fertilizers (Naderi and Danesh-Shahraki 2013).

\section{Zinc-Based Nano fertilizers}

Among the metal- and metal oxideengineered nanomaterials, zinc $(Z n)$ and zinc oxide $(\mathrm{ZnO})$ are commonly applied on plants. One of the widely spread micronutrient deficiency in soil is zinc deficiency, and Stella et al. (2010) reported that it is the fourth most important yield-limiting nutrient after nitrogen, phosphorus, and potassium. Due to its extensive utilization in consumer products, it is likely that 
either through accidental release or deliberate applications, the $\mathrm{Zn}$ or $\mathrm{ZnO}$ might enter into atmospheric environments. This may further lead to considerable effect on many organisms, particularly plants which are the essential base component of all ecosystems (Dwivedi and Randhawa 1974). Zinc-containing nanomaterials are needed for chlorophyll production, fertilization, pollen function, and synthesis of auxins. Among the micronutrients, it is $\mathrm{Zn}$ that protects the plants from drought stress (Sharma et al. 2009). Zinc and $\mathrm{ZnO}$ may also affect the germination rate of the seeds. The effect of $\mathrm{ZnO}$ on root germination was observed for the species of Buck wheat (Fagopyrum esculentum) (Sooyeon et al. 2013). The $\mathrm{ZnO}$ nanoparticles had pronounced effect on onion (Allium cepa) root elongation, genetic composition, and metabolism. The seed soaking and incubation in the suspension of $\mathrm{Zn} / \mathrm{ZnO}$ nanoparticles halted the growth of roots in corn. The toxicity of $\mathrm{ZnO}$ nanoparticle and $\mathrm{Zn}^{2+}$ could be driven by different theories, either it could be due to the chemical toxicity based on chemical composition or it could be due to the stress or stimuli imposed by size, shape, and surface of the $\mathrm{ZnO}$ nanoparticles. Both the theories affected the cell culture response of the plants. Depending on the plant species and the experimental conditions, the most important mechanism of action may be internal efficiency, i.e., $\mathrm{Zn} / \mathrm{ZnO}$ utilization in tissues, or $\mathrm{Zn} / \mathrm{Zn}$ uptake which is regarded as external efficiency (Dwivedi and Randhawa 1974). This deliberated the $\mathrm{ZnO}$ nanoparticles to enter the root cells and inhibit seedling growth. The seed germination and root growth study of zucchini seed in hydroponic solution containing $\mathrm{ZnO}$ nanoparticles showed no negative response (Stampoulis et al. 2009), whereas seed germination in rye grass and corn was inhibited by nanoscale zinc and $\mathrm{ZnO}$, respectively. It was confirmed by electron microscopy that the uptake of nanoparticles $\mathrm{ZnO}$ damaged epidermal and cortical cells and could also injure the endodermal and vascular cells causing growth inhibition in rye grass (Lin and Xing 2007).

The ZnO NPs were absorbed by the plant roots and circulated equivalently throughout the plant tissues. But All ENPs may not be similarly operative for all crops. Unlike $\mathrm{CeO} 2 \mathrm{NPs}, \mathrm{ZnO}$ NPs were found to be translocated into above ground plant tissue, suggesting that uptake and translocation are dependent on NP type (Priestera et al. 2012). The ZnO NPs were absorbed by the plant roots and circulated equivalently throughout the plant tissues. But All ENPs may not be similarly operative for all crops. Unlike $\mathrm{CeO} 2 \mathrm{NPs}$, ZnO NPs were found to be translocated into above ground plant tissue, suggesting that uptake and translocation are dependent on NP type (Priestera et al. 2012). Uptake and accumulation of ZnO NPs (8 $\mathrm{nm}$ ) were investigated in soybean (Glycine max) seedlings at the range of $500-4000 \mathrm{mg} \mathrm{L}^{-1}$. The uptake of Zn NPs by the soybean seedlings was significantly higher at $500 \mathrm{mg} \mathrm{L}^{-1}$ than the concentrations at $1000 \mathrm{mg} \mathrm{L}^{-1}$ and above. This may be because at lower concentration $(500 \mathrm{mg}$ $\mathrm{L}^{-1}$ ), the NPs have lesser aggregation, whereas at high concentrations $\left(1000-4000 \mathrm{mg} \mathrm{L}^{-1}\right)$, the probability of agglomerates formation is proposed. Passage of oversized agglomerates through the cell pore walls, therefore, becomes problematic. This ultimately reduces uptake and accumulation in case of ZnO NPs as understood from the results (Lopez-Moreno et al. 2010a). $\mathrm{ZnO} N \mathrm{~N}$ s were absorbed as $\mathrm{Zn}^{2+}$ oxidation state by hydroponically grown soybean plants. Later, it was hypothesized that $\mathrm{ZnO} N P s$ transformed in $\mathrm{Zn}^{2+}$ oxidation state at the root surface (LopezMoreno et al. 2010a). Similar results were also reported by Dimkpa et al. (2013) and Wang et al. (2013a, b, c). Raliya and Tarafdar (2013) found that $\mathrm{ZnO}$ NPs were instrumental in significantly improving the chlorophyll content and protein synthesis, rhizospheric microbial population, acid phosphatase, alkaline phosphatase, and phytase activity in a cluster bean rhizosphere. ZnO NPssupplemented MS media induced proline synthesis and increased activity of superoxide dismutase (SOD), catalase (CAT), and peroxidase resulting in heightened tolerance to biotic stress.

Hernandez-Viezcas et al. (2011) studied the effects of $10 \mathrm{~nm} \mathrm{ZnO} \mathrm{NPs} \mathrm{in} \mathrm{hydroponic}$ cultures of velvet mesquite at concentrations varying from 500 to $4000 \mathrm{mg} \mathrm{L}^{-1}$. To evaluate NP-induced stress on the plant, specific activity of catalase and ascorbate peroxidase (APX) was performed. The NPs were recorded to increase the specific activity of CAT (in the root, stem, and leaves) and APX (only in the leaves), while no evidence of detrimental aspects as chlorosis, necrosis, stunting, or wilting, even after 30 days of treatment, was observed, suggesting a 
significant tolerance level toward $\mathrm{ZnO}$ NPs. Kumari et al. (2011) during the evaluation of effects of $\mathrm{ZnO}$ NPs using root cells of onion showed that on increasing the ZnO NPs or the $\mathrm{ZnO}$ bulk concentrations, higher values for the thiobarbituric acid reactive species (TBARS) were observed. During reactive oxygen species (ROS) formation and release, fatty acid conversion to toxic lipid peroxides occurs, causing disruption of biological membranes facilitating the entry of and damage by NPs and metals, resulting in TBARS formation, which damages the membrane permeability and is predicted to be one the reasons for the observed phytotoxicity. ZnO NPs have been found to associate with highly vacuolated and collapsed cortical cells along with the shrinking and partial death of the vascular cells (Lin and Xing 2008). An experiment with foliar application of different concentrations of $\mathrm{ZnO}$ NPs $\left(0-100 \mathrm{mg} \mathrm{L}^{-1}\right)$ solution in tomato plants grown in pots revealed that $20 \mathrm{mg} \mathrm{mL}-1$ zinc oxide nanoparticle solution recorded maximum growth and biomass production (Panwar et al. 2012; De Rosa et al. 2013).In most of the studies, the effect of ZnONPs on plant growth depends on concentration. Root elongation in soybean was reported at $500 \mathrm{mg} \mathrm{L}^{-1}$, whereas higher concentrations resulted in the reduction of root length. No effect on seed germination in soybean was observed at even higher concentration (4000 $\mathrm{mg} \mathrm{L}^{-1}$ ) (López-Moreno et al. 2010). Mahajan et al. (2011) demonstrated the effect of nano- $\mathrm{ZnO}$ particles on the growth of plant seedlings of mung bean and chick pea (Cicer arietinum). ZnO NPs showed concentration-dependent growth pattern in mung bean and chick pea seedlings. The maximum growth was found at 20 ppm for mung bean and $1 \mathrm{ppm}$ for chick pea seedlings, and beyond this concentration, the growth was inhibited.

and $40 \mu \mathrm{g} \mathrm{ml}^{-1}$ ) of $\mathrm{ZnO}$ NPs at the interval of 15 days. The growth parameters including plant height and number of leaves per plant were assessed at the time of flowering, and the seed yield parameters such as number of seeded fruits per umbel, seed yield per umbel, and 1000-seed weight were determined at the time of harvest. Seed samples obtained from treated plants along with control were tested for germination and early seedling growth. Results revealed that the plants treated with ZnO NPs at
Prasad et al. (2012) suggested variable response of peanut seeds toward the treatment at various concentrations of both bulk $\mathrm{ZnSO}_{4}$ and nano scale $\mathrm{ZnO}$ particles. The postharvest leaf and kernel samples were analyzed to estimate the zinc content and showed favourable effect. Absorption of $\mathrm{ZnO}$ NPs by plants was more as compared to $\mathrm{ZnSO} 4$ bulk. Results also revealed the beneficial effects of NPs in enhancing plant growth, development, and yield in peanut at lower doses (1000 ppm), but at higher concentrations (2000 ppm), ZnO NPs were detrimental just as the bulk nutrients. Pod yield per plant was $34 \%$ higher in plants treated with $\mathrm{ZnO}$ as compared to chelated bulk $\mathrm{ZnSO}_{4}$. Scanning electron microscopy and energy dispersive analysis of X-rays (SEM-EDAX) showed $\mathrm{Zn}$ uptake by the peanut (Arachis hypogea) seeds treated with nanoscale $\mathrm{ZnO}$. Thin sections of the peanut embryo were analyzed by SEM. Although, an expected, low $\mathrm{Zn}$ concentration in peanut seeds was observed in EDAX spectra, EDAX images confirmed that the regions showing higher $\mathrm{C}$ and $\mathrm{N}$ concentrations also exhibited high accumulation of $\mathrm{Zn}$ in the seeds treated with nanoscale ZnO.Similar findings were reported by Raliya and Tarafdar (2013) on shoot length, root length, root area, and plant biomass in cluster bean (Cymopsistetragonoloba), when 10 ppm ZnO NPs were foliar-sprayed on leaf of 14-day-old plant. Significant improvement was observed in shoot length $(31.5 \%)$, root length $(66.3 \%)$, root area $(73.5 \%)$, and plant biomass $(27.1 \%)$ over control in 6weekold plants because of the treatment with $\mathrm{ZnO}$ NPs.

The effect of $\mathrm{ZnO}$ NPs on growth, flowering, and seed productivity of onion was studied (Laware and Raskar 2014). Six-monthaged onion bulbs (cut in half portions) were subjected to pot plantation and sprayed three times with varying concentrations $(0,10,20,30$, the concentration of 20 and $30 \mu \mathrm{g} \mathrm{ml}^{-1}$ showed better growth and flowered 12-14 days earlier in comparison with control. Treated plants showed significantly higher values for seeded fruits per umbel, seed weight per umbel, and 1000-seed weight over control plants. It was confirmed that high-quality seed along with all other inputs (size, number, etc.) was responsible for enhancement in final yield. These results indicated that $\mathrm{ZnO}$ NPs can reduce flowering period in onion by 12-14 days and produce high- 
quality healthy seeds. The increase in vegetative growth in onion might be related to the fundamental role of $\mathrm{ZnO}$ in maintenance and protection of structural stability of cell membranes (Welch et al. 1982) and involvement in protein synthesis, functioning of membrane, cell elongation, as well as tolerance to various environ- mental stresses (Cakmak 2000).

Kisan et al. (2015) in another study examined the effect of nano- $\mathrm{ZnO}$ on the leaf physical and nutritional quality of spinach. The spinach plants were sprayed with varying concentrations $(0,100,500$, and $1000 \mathrm{ppm})$ of ZnO NPs after 14 days of sowing. At the time of maturity (45-50 days), the leaf physical parameters such as leaf length, leaf width, and leaf surface area were noted and nutritional parameters such as protein, carbohydrate, fat, and dietary fiber contents in leaf samples were determined. When 500 and 1000 ppm concentration of $\mathrm{ZnO}$ NPs were sprayed, increase in leaf length, width, surface area, and color of spinach leaves were recorded with respect to control. Similarly, elevated levels of protein and dietary fiber contents were observed in plants treated with $\mathrm{ZnO} N \mathrm{NS}$ at the concentration of 500 and $1000 \mathrm{ppm}$ in comparison with control leaf samples of spinach. It was proposed that the nano-zinc oxide has a potential to be used as a biofortification agent for the improvement of protein and dietary fiber contents of spinach leaves and thereby reduces malnutrition. The positive effect of the application of zinc oxide nanoparticles on tomato plants opens an avenue for its potential use as a future nanofertilizer. An experiment with foliar application of different concentrations of $\mathrm{ZnO}$ NPs $\left(0-100 \mathrm{mg} \mathrm{L}^{-1}\right)$ solution in tomato plants grown in pots revealed that $20 \mathrm{mg} \mathrm{mL}-{ }^{1}$ zinc oxide nanoparticle solution recorded maximum growth and biomass production (Panwar et al. 2012; De Rosa et al. 2013).

microscopy (STEM) images of radish (Raphanus sativus) shoot samples did not reveal any significant evidence of electron-dense deposits, and energy dispersive spectroscopy (EDS) analysis did not reveal specific elemental signals for $\mathrm{Cu}$ in either control samples or samples exposed to $500 \mathrm{mg} / \mathrm{L} \mathrm{NPs} \mathrm{(Atha} \mathrm{et} \mathrm{al.} \mathrm{2012).}$ Hafeez et al. (2015) examined the potential of copper NPs to increase growth and yield of wheat. The growth and yield were significantly increased in comparison with control when $\mathrm{Cu}$
Effect of nanoparticles on germination and seed quality enhancement has been reported by Shyla and Natarajan (2014). The beneficial effects of ZnO NPs in improving seed germination could be due to higher precursor activity of nanoscale zinc in auxin production. Moreover, zinc is required for plant growth and is essential for various enzymes catalyzing various steps. Raliya and Tarafdar (2013) reported significant improvement in the gum content and its viscosity in cluster bean seeds at crop harvest when the leaf of 14-day-old plant was foliarsprayed with $10 \mathrm{mg} \mathrm{L}-1 \mathrm{ZnO}$ NPs. Improved growth parameters and gum content might be due to adsorption of NPs on plant surface and taken up by the plants through natural nano- or microscale openings.

\section{Copper-Based Nano fertilizers}

CuO NPs were transported to the shoots and translocated back to the roots via phloem (Shankar et al. 2003). CuO NPs were taken up by maize and wheat in the particulate form (Dimkpa et al. 2012, 2013; Wang et al. 2012a, b). Uptake and translocation of Cu NPs in mung bean (Vigna radiata) and wheat in agar growth medium were evaluated. The results showed that the $\mathrm{Cu}$ NPs were able to cross the cell membrane and agglomerate in the cells. A significant relationship between the bioaccumulated NPs in plant tissues and growth media was also established. It was also noticed that mung bean was more sensitive than wheat to toxicity of $\mathrm{Cu}$ NPs probably due to root anatomical differences (Lee et al. 2008; Rico et al. 2011).Copper NPs exhibited greater ability for uptake in shoots than copper bulk particles (BPs). Results revealed that total uptake into the shoots was approximately three times greater for the NPs. Scanning transmission electron

NPs (at 10, 20, 30, 40, and 50 ppm) were applied to soil in pots. However, the significant increase in the chlorophyll content, leaf area, number of spikes/pot, number of grains/spike, 100 -grain weight, and grain yield was observed at $30 \mathrm{ppm} \mathrm{Cu}$ NPs. Results revealed that the enhanced growth and yield in wheat due to $\mathrm{Cu}$ NPs are concentration-dependent and further experimentation is required for the dose optimization and mode of application to maximize the yield of wheat. 


\section{IFFCO VENTURES INTO R\&D AND MANUFACTURING OF NANO- FERTILIZERS}

IFFCO explored the innovative approaches to develop nano-N (urea), nano $\mathrm{Zn}$ and nano $\mathrm{Cu}$ through nanotechnology to increase NUE for increasing crop yields; reduce bulk fertilizer's consumption and increase farmer's profitability at reduced environmental cost. To achieve these objectives, Nano Biotechnology Research Centre (NBRC\} at Kalol, Gandhinagar, Gujarat was established by IFFCO on $3^{\text {rd }}$ November, 2019. NBRC has indigenously developed proprietary patented three products - nano nitrogen, nano zinc and nano copper. These nano scale nutrients have desired particle shape, particle size, particle purity, composition, concentration, stability, polydispersity index (PDIvalue), $\mathrm{pH}$ and crystal phase. They are bio available and within the scientific limits of application (10 to 80 ppm) as per their desired content in plants thus, fulfilling plant nutritional requirement as a fertilizer.

\section{IFFCO Nano Urea}

Nano nitrogen based on principles of nano technology provides novel alternative to wean the farmers away from urea. Nano scale advantages of nitrogen particles have to be leveraged for addressing effectively the nitrogen requirement of crops (Figure 2). Precision and targeted application of nitrogen through foliar application of nano nitrogen reduces urealosses; increases nutrient uptake efficiency; and addresses environmental issues of soil, air and water pollution. It results in better crop harvest with lesser nitrogen application per unit area thus, leading to better farm economics.

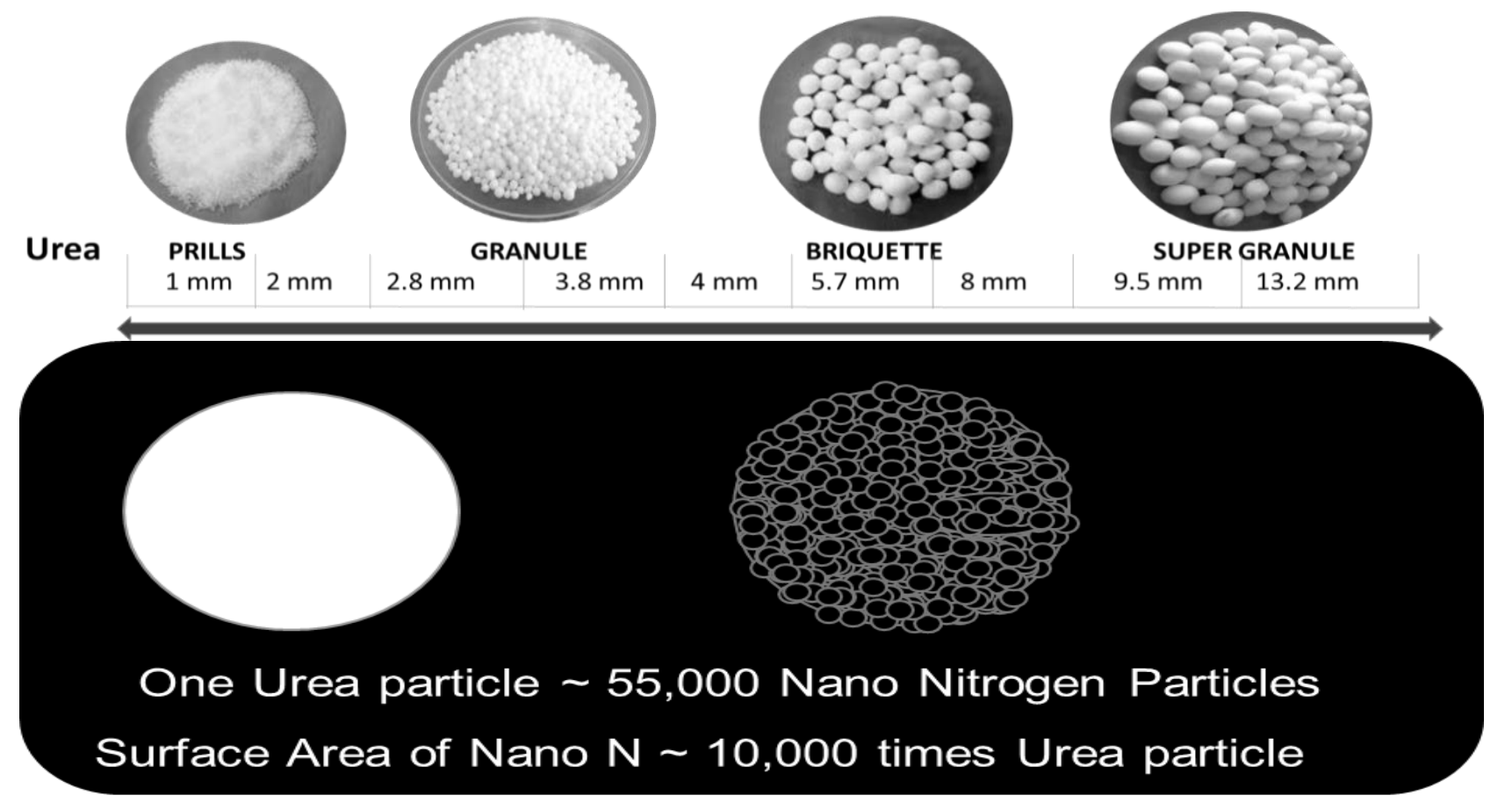

Figure 2: Nanoscale Advantage - Dynamics of size, shape and mode of action Nano fertilizers role in sustainable agriculture

Spraying of nano nitrogen at the rate of 2-4 mL per litre of water at critical crop growth stages triggers crop response, fulfils its nutritional requirement and also improves nutrient availability in the rhizosphere. When sprayed on leaves, nano $\mathrm{N}$ fertilizer easily gets absorbed and also enters through stomata due to its nano size $(<100 \mathrm{~nm})$ (Figure3). It is distributed too their plant parts through phloem translocation and metabolically assimilated as proteins, amino acids, etc. as per the plant's need. 


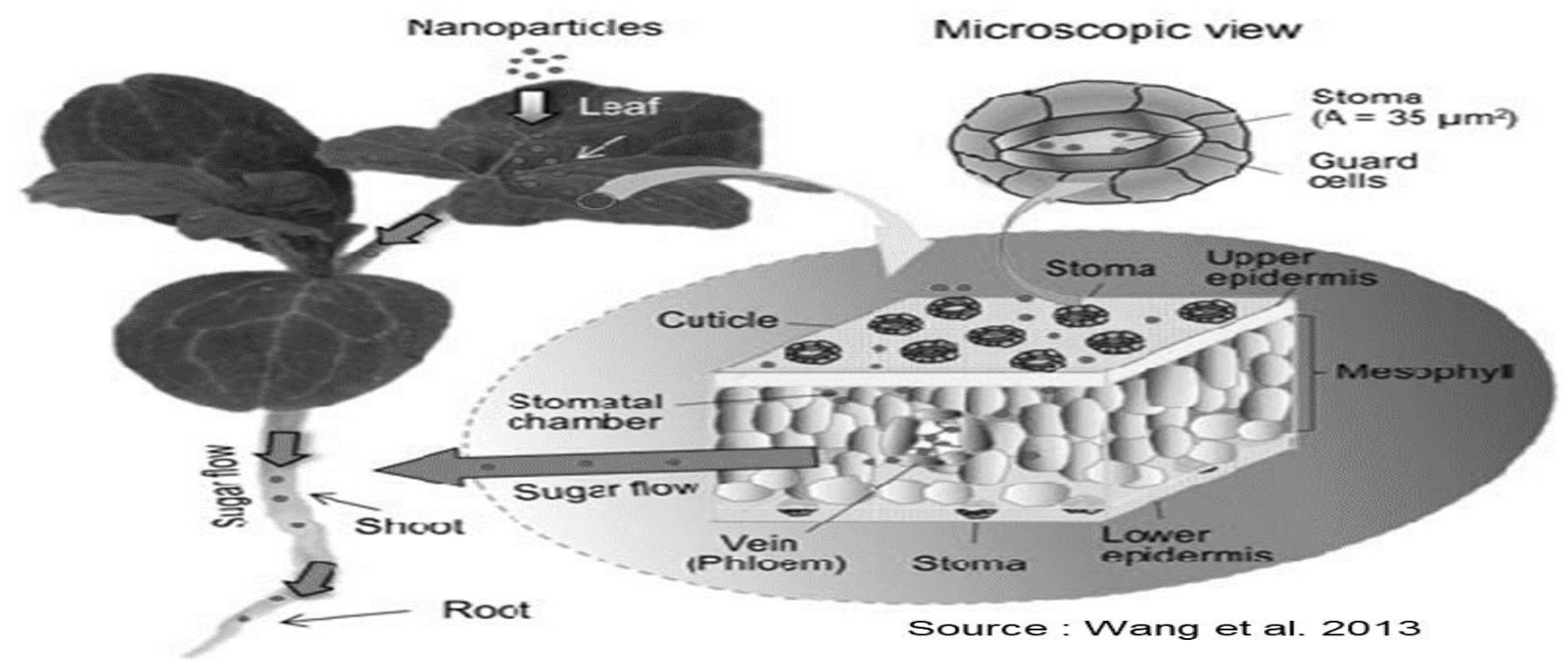

Figure 3: Entry, transport and translocation of nanoscale particles inside the plant system (Wang et al. 2013)

Nano urea contains nanoscale nitrogen particles $(30-50 \mathrm{~nm})$ which have more surface area $(10,000$ times over $1 \mathrm{~mm}$ urea prill) and number of particles $(55,000$ nitrogen particles over $1 \mathrm{~mm}$ urea prill). Nano nitrogen particles with pore size $(20 \mathrm{~nm})$ can easily penetrate through cell wall and reach up to plasma membrane. Large size particles (30 - $50 \mathrm{~nm}$ ) can penetrate through stomatal pores. They are also transported via phloem cells through plasmodesmata (40 $\mathrm{nm}$ diameter) to other plant parts. They can bind to carrier proteins through aquaporin, ion channels, and through endocytosis and metabolized inside the plant cell. Thus, when applying nanoscale particle like nano nitrogen through foliar application, it leads to more efficient absorption and penetration of nitrogen in-seed production.

\section{IFFCO's Nano Zn and Nano Cu}

Plants meet their $\mathrm{Zn}$ and $\mathrm{Cu}$ requirements from soils but because of increasing micronutrient deficiencies, bulk fertilizers are being applied to meet crop demand of these nutrients. Current fertilizer options are not efficient because of their poor use efficiency insoil. Primary aim of nano zinc and nano copper is to substitute their conventional fertilizer analogues which have use efficiency between 2-5\%, increase crop productivity, and enhance its quality through agronomic fortification. Furthermore, nano zinc also helps plant to take up more $\mathrm{P}$, leads to better physiological growth, and brings uniformity in shape and size of fruits. Similarly, nano copper builds innate immunity of crops against harm ful fungal and bacterial pathogens which affects their overall growth and development. When nano zinc and nano copper are sprayed on the leaves because of small size they can be easily absorbed by the plant either directly or through stomatal openings. On entering through the leaves, these are distributed to plant parts through phloem translocation and metabolically assimilated as per the plant's need.

\section{IFFCO Nano Zinc}

Zinc is essentially required by the plants, animals and human beings for their proper growth and development. Human requires zinc through their diet drawn directly or indirectly from plants. Zinc deficiency in Indian soils is quite large. Among the metal and metal oxideengineered nanomaterials, zinc ( $Z n)$ and zinc oxide $(\mathrm{ZnO})$ are commonly applied on plants.

\section{IFFCO Nano Copper}

Copper is also one of the eight essential plant micronutrients, required for plant metabolic activities and healthy seed production. Copper deficiency can lead to increased susceptibility to pathogenic fungal and bacterial diseases, which can cause significant yield losses. Cu NPs were able to 
cross the cell membrane and agglomerate in the cells. A significant relationship between the bio accumulated NPs in plant tissues and growth media has been established.

For better results, nano zinc or nano copper are sprayed two times at critical growth stages of the plant, first during initial growth stages and second at the pre-flowering stage with rate of application being 2-4 $\mathrm{mL}$ per tree of water. Nano zinc and nano copper can be mixed together during spray, if needed; else, they can be used separately. IFFCO nano zinc andnano copper can be used for all the crops such as legumes, cereals, oilseeds, vegetables and fruit.

\section{(a) Multilocation-MultiCrop On - Station Trials of Nano-fertilizers}

IFFCO launched nanotechnologybased indigenous nano products-nano nitrogen, nano zinc and nano copper on $3^{\text {rd }}$ November, 2019 and simultaneously, undertook11,000 farmers' field trials (FFTs) and "On Station" trials in collaboration with 22 State Agricultural Universities (SAUs)/Research institutes. Experimental trials undertaken during rabi-zaid 2019- 20 in different crops like paddy, wheat, mustard, maize, tomato, cabbage, cucumber, capsicum, onion and states have recorded encouraging results. Summary of State Agricultural Universities /ICAR-KVK trials indicate that nano nutrient can enhance farmer's crop yields, besides effecting substantial savings on subsidised bulk fertilizer applications.

$$
\text { Trials conducted with }
$$

SAUs/Research Institutes indicate that 50\% urea reduction is possible with foliar application of nano nitrogen. All the growth and yield contributing characters were maximum and significantly superior in treatments receiving 2 sprays of nano nitrogen or alternate combination sprays of nano nitrogen, nano zinc and nano copper with $50 \%$ reduction in nitrogen and zinc wherever recommended. ICAR-Indian Agricultural Research Institute, New Delhi states that nano fertilizers (alone or in combination) when applied with graded doses of fertilizers can lead toup to $50 \%$ reduction in the fertilizer nitrogen. Curtailing of $25 \%$ nitrogen fertilizer in wheat and $50 \%$ nitrogen fertilizer in mustard is possible with the two sprays of nano nitrogen. Similar or better results have been conveyed by other research institutes and SAUs. More number of effective tillers, higher growth and biomass yields and grain and straw yield has been recorded in treatments receiving nanofertilizer application. Mahatma Phule Krishi Vidyapeeth, Rahuri evaluated nano products on onion crop and found that nano nitrogen and nano zinc increased yield even when their conventional counterpart application dose was reduced by $50 \%$ and Nano Copper improved the fruit quality. Economic benefits i.e. BCR of nanofertilizer application have to be seen in terms of extra yield achieved along with reduction in fertilizer us age and direct-indirect benefits on there duction of soil-air- water pollution level.

\section{(b) Multi location-Multi Crop-On-Farm Trials of Nanofertilizers}

Farmer field trials have confirmed that IFFCO Nano Nitrogen leads to reduction in urea usage and better economics for the farmers. 9037 successful "Farmer Field Trials - FFT's" on 94 crops conducted in close supervision with ICAR- KVKs across 28 states / UTs were recorded. In farmers field trials average 7-8\% higher crop yield have been recorded with $50 \%$ less urea application.

Results of 600 on-farm trials with 8 crops conducted during winter season in different districts of Rajasthan have proved that the quantity of urea being applied by the farmers to supply nitrogen to the crops can be successfully reduced to half (Table 3 ). The yields obtained with $50 \%$ less nitrogen plus 2 sprays of nanonitrogen in standing crops gave yields higher than that applied in most of the 8 crops tested in these trials. Apart from this, effect of the Nano$\mathrm{Zn}$ and Nano-Cu was also evaluated. As the deficiencies of these micronutrients were not universal like nitrogen, the significant responses to these nano fertilizers depended on the magnitude of deficiency of specific micronutrients and the nature of the crops. Results of 730 field demonstrations conducted in different districts of Uttar Pradesh on farmers' fields with 12 crops proved that with the use of nano-nitrogen (Nano-N), the quantity of urea 
Table 3: Effect of Nano fertilisers on Crops (Table derived from "Results of Farmer Field trials conducted in Rajasthan \& Uttar Pradesh-2019-20"

\begin{tabular}{|c|c|c|c|c|c|c|}
\hline $\begin{array}{l}\text { Crop (Data in } \\
\text { parenthesis are } \\
\text { number of trials) }\end{array}$ & Parameters\# & $\begin{array}{c}\text { Farmer } \\
\text { Fertilizer } \\
\text { Practice (FFP) }\end{array}$ & $\begin{array}{l}\text { FFP }-50 \% \mathrm{~N} \\
+2 \text { Spray of } \\
\text { Nano }-\mathrm{N} \\
\end{array}$ & $\begin{array}{l}\text { FFP }+2 \\
\text { Spray of } \\
\text { Nano }-Z n\end{array}$ & $\begin{array}{l}\text { FFP }+2 \\
\text { Spray of } \\
\text { Nano Cu }\end{array}$ & $\begin{array}{c}\text { FFP }(-50 \% N)+1 \text { Spray of } \\
\text { Nano-N+ } 1 \text { Spray of Nano- } \\
Z n+1 \text { Spray of Nano-Cu }\end{array}$ \\
\hline \multirow{6}{*}{ Wheat (480) } & Lowest yield $\left(\mathrm{kg} \mathrm{ha}^{-1}\right)$ & 2250 & 2400 & 2370 & 2370 & 2380 \\
\hline & Highest yield ( $\mathrm{kg} \mathrm{ha}^{-1}$ ) & 6410 & 6760 & 6610 & 6580 & 6875 \\
\hline & Mean yield $\left(\mathrm{kg} \mathrm{ha}^{-1}\right)$ & 4330 & 4580 & 4490 & 4475 & 4628 \\
\hline & Response over FFP $\left(\mathrm{kg} \mathrm{ha}^{-1}\right)$ & - & 250 & 160 & 145 & 297.5 \\
\hline & Per cent increase over FFP & - & 5.77 & 3.7 & 3.35 & 6.87 \\
\hline & Net return over FFP (Rs. ha-1) & - & 4812.50 & 3080.00 & 2791.25 & 5726.88 \\
\hline \multirow{6}{*}{ Barley (9) } & Lowest yield $\left(\mathrm{kg} \mathrm{ha}^{-1}\right)$ & 3200 & 3380 & 3300 & 3250 & 3350 \\
\hline & Highest yield ( $\mathrm{kg} \mathrm{ha}^{-1}$ ) & 5260 & 5620 & 5730 & 5790 & 5900 \\
\hline & Mean yield $\left(\mathrm{kg} \mathrm{ha}^{-1}\right)$ & 4230 & 4500 & 4515 & 4520 & 4625 \\
\hline & Response over FFP $\left(\mathrm{kg} \mathrm{ha}^{-1}\right)$ & - & 270 & 285 & 290 & 395 \\
\hline & Per cent increase over FFP & - & 6.38 & 6.74 & 6.86 & 9.34 \\
\hline & Net return over FFP (Rs. ha-1) & - & 4117.50 & 4346.25 & 4422.50 & 6023.75 \\
\hline \multirow{6}{*}{ Maize (4) } & Lowest yield $\left(\mathrm{kg} \mathrm{ha}^{-1}\right)$ & 4100 & 4300 & 4400 & 4100 & 4500 \\
\hline & Highest yield ( $\left.\mathrm{kg} \mathrm{ha}^{-1}\right)$ & 5500 & 6000 & 5700 & 5550 & 6000 \\
\hline & Mean yield $\left(\mathrm{kg} \mathrm{ha}^{-1}\right)^{\prime}$ & 4800 & 5150 & 5050 & 4825 & 5250 \\
\hline & Response over FFP $\left(\mathrm{kg} \mathrm{ha}^{-1}\right)$ & - & 350 & 250 & 25 & 450 \\
\hline & Per cent increase over FFP & - & 7.29 & 5.21 & 0.52 & 9.38 \\
\hline & Net return over FFP (Rs. ha $\left.{ }^{-1}\right)$ & - & 6160 & 4400 & 440 & 7920 \\
\hline \multirow{6}{*}{ Chickpea (27) } & Lowest yield $\left(\mathrm{kg} \mathrm{ha}^{-1}\right)$ & 1437 & 1566 & 1498 & 1466 & 1677 \\
\hline & Highest yield ( $\mathrm{kg} \mathrm{ha}^{-1}$ ) & 2500 & 2700 & 2650 & 2600 & 2650 \\
\hline & Mean yield $\left(\mathrm{kg} \mathrm{ha}^{-1}\right)$ & 1969 & 2133 & 2074 & 2033 & 2164 \\
\hline & Response over FFP $\left(\mathrm{kg} \mathrm{ha}^{-1}\right)$ & - & 165 & 106 & 65 & 195 \\
\hline & Per cent increase over FFP & - & 8.36 & 5.36 & 3.28 & 9.91 \\
\hline & Net return over FFP (Rs. ha ${ }^{-1}$ ) & - & 8019.38 & 5143.13 & 3144.38 & 9506.25 \\
\hline \multirow{6}{*}{ Urdbean (3) } & Lowest yield $\left(\mathrm{kg} \mathrm{ha}^{-1}\right)$ & 1650 & 1850 & 1925 & 1750 & 1975 \\
\hline & Highest yield $\left(\mathrm{kg} \mathrm{ha}^{-1}\right)$ & 1700 & 1850 & 2000 & 1800 & 2150 \\
\hline & Mean yield $\left(\mathrm{kg} \mathrm{ha}^{-1}\right)$ & 1675 & 1850 & 1963 & 1775 & 2063 \\
\hline & Response over FFP $\left(\mathrm{kg} \mathrm{ha}^{-1}\right)$ & - & 175 & 288 & 100 & 388 \\
\hline & Per cent increase over FFP & - & 10.45 & 17.16 & 5.97 & 23.13 \\
\hline & Net return over FFP (Rs. ha $\left.{ }^{-1}\right)$ & - & 9975 & 16387.50 & 5700 & 22087.50 \\
\hline \multirow{5}{*}{ Mustard (70) } & Lowest yield $\left(\mathrm{kg} \mathrm{ha}^{-1}\right)$ & 1100 & 1200 & 1170 & 1120 & 1180 \\
\hline & Highest yield ( $\mathrm{kg} \mathrm{ha}^{-1}$ ) & 4200 & 4300 & 4500 & 4200 & 4600 \\
\hline & Mean yield $\left(\mathrm{kg} \mathrm{ha}^{-1}\right)^{\prime}$ & 2650 & 2750 & 2835 & 2660 & 2890 \\
\hline & Response over FFP $\left(\mathrm{kg} \mathrm{ha}^{-1}\right)$ & - & 100 & 185 & 10 & 240 \\
\hline & Per cent increase over FFP & - & 3.77 & 6.98 & 0.38 & 9.06 \\
\hline & Net return over FFP (Rs. ha ${ }^{-1}$ ) & - & 4425 & 8186.25 & 442.50 & 10620 \\
\hline \multirow[t]{2}{*}{ Potato (187) } & Lowest yield & 13250 & 15000 & 14000 & 14000 & 16000 \\
\hline & Highest yield & 61200 & 64300 & 61800 & 61800 & 62700 \\
\hline \multirow{10}{*}{ Lentil (5) } & Mean & 32298 & 35414 & 33568 & 33824 & 34798 \\
\hline & Response over FFP, kg/ha & - & 3117 & 1270 & 1526 & 2500 \\
\hline & $\%$ Increase over FFP & - & 9.65 & 3.93 & 4.72 & 7.74 \\
\hline & Net Return over FFP, Rs./ha & - & 31165 & 12702 & 15259 & 24997 \\
\hline & Lowest yield $\left(\mathrm{kg} \mathrm{ha}^{-1}\right)$ & 625 & 680 & 665 & 660 & 650 \\
\hline & Highest yield $\left(\mathrm{kg} \mathrm{ha}^{-1}\right)$ & 2019 & 2056 & 2032 & 2038 & 2024 \\
\hline & Mean yield $\left(\mathrm{kg} \mathrm{ha}^{-1}\right)$ & 1677 & 1715 & 1696 & 1696 & 1689 \\
\hline & Response over FFP $\left(\mathrm{kg} \mathrm{ha}^{-1}\right)$ & - & 37 & 19 & 19 & 12 \\
\hline & Per cent increase over FFP & - & 2.23 & 1.11 & 1.13 & 0.72 \\
\hline & Net return over FFP (Rs. ha $\left.{ }^{-1}\right)$ & - & 1795 & 893 & 912 & 576 \\
\hline
\end{tabular}

\#Straw yield/ by products yield will be separate, Source: Yogendra Kumar et al. (2020 a and b)

being applied by the farmers to supply nitrogen to their crops can be successfully reduced to half (Table 3).

The yields obtained with $50 \%$ less nitrogen as compared to the $\mathrm{N}$ applied under farmers fertilizer practice (FFP) and applying 2 sprays of Nano- $\mathrm{N}$ in standing crops gave yields higher than FFP in most of the crops tested in these demonstrations. Apart from this, effect of Nano-Zn and Nano-Cu was also evaluated. As the deficiencies of micronutrients are not universal like $\mathrm{N}$, positive responses to these nanofertilizers depended on the magnitude of the deficiency of specific nutrient [zinc (Zn) or copper $(\mathrm{Cu})$ ] and the nature of the crops.

These results clearly establish that with application of nanofertilizers, the nutrient use efficiency can be significantly enhanced as revealed by 50 per cent saving of urea through 2 sprays of Nano N. Nanofertilizers are considered as a novel approach towards saving of nutrients, in particular nitrogen, and for protecting the environment. 


\section{PROSPECTS OF IFFCO NANO UREA, NANO ZINC AND NANOCOPPER}

IFFCO nano urea, nano zinc and nano copper are in sync with OECD testing guidelines (TGs) and "Guidelines for Testing of Nano Agri inputs (NAIPs) and Food Products released by the Department of Biotechnology, Government of India. Harvested produce of crops applied with IFFCO's nano urea, nano zinc and nano copper have been found to be fit for consumption with no adverse effect. These are safe for application, both to the user and for the environment. These have other incremental benefits such as these are costeffective and can be applied in rainfed and dry land agriculture as well as in protected cultivation. These are also compatible with most of the agrochemicals, biostimulants and specialty fertilizers. Independently, nano nitrogen, nano zinc and nano copper have also been proactively tested for bio- efficacybiosafety- toxicity and environment suitability by NABL-accredited and GLPcertified laboratories. IFFCO nanofertilizers meet all the current national and international guidelines related to nanotechnology or nano scale agri-inputs. It is for the first time in the world that nano nitrogen (Nano Urea- liquid) has been introduced to the farmers. With inclusion of nano- fertilizers such as Nano Urea in schedule VII of FCO 1985 , its production will be undertaken by IFFCO so that farmers can ultimately benefit from the boon of nanotechnology. It will be a step in the direction of self-reliance in terms of 'ATMANIRBHAR BHARAT' and 'ATMANIRBHAR KRISHI' because of nanofertilizers.

\section{EPILOGUE}

Agriculture is the backbone of Indian economy utilizing both renewable and nonrenewable resources but ensuring food security to the masses. Increasing consumer awareness regarding food traceability, environment friendly agri-inputs and sustainable farm operations calls for revisiting agriculture through introduction of novel and innovative solutions like nanofertilizers.
Nitrogen pollution (NO3-, $\mathrm{NH} 4+, \mathrm{N} 2 \mathrm{O}$ ) has emerged as a major factor responsible for environment pollution which is being targeted globally for reduction in a phased manner. It is one of the components of Paris agreement for climate change and UN sustainable development goals (SDGs). Excessive nitrogen application in agriculture has to be reduced in a phased manner for ensuring healthy environment and soil-crop-atmospheric biodiversity in perpetuity. Reduction in excessive fertilizer application has cascading effect in improvement of overall crop economy and environment resilience.

Nanotechnology has emerged as an innovative solution which has multiple applications in various fields besides agriculture. World over more than 1200 nano-tech based commercial products have found place as products and their variants in consumer and industrial space. Nano products have definitive advantage in terms of size, shape, quantity and efficacy. They can address constraints faced at the level of scale and scope in terms of environment sustainability and resource conservation. Through nano agri inputs nutritional requirement of crops can be effectively met through targeted, stage wise and slow release application without disturbing the agro- ecology.

Novelty of nano-fertilizers lies in their unique size, composition and properties. Their application enhances bio availability of nutrients due to triggering of alternative pathways and enzymes inside the plant system, increase in root biomass and rhizospheric microbial population which results in more availability of nutrients. Nano-fertilizer application can be further streamlined as per focus crop nutrient uptake and removal studies over a period of time so that they can be effectively integrated in the package of practices (POPs) of states and as an effective component of $4 \mathrm{R}$ technique. Nano products especially IFFCO nano urea should be viewed in this backdrop.

Nanofertilizers have to be looked upon as an alternative option made available to farmers engaged in residue free organic and sustainable agriculture. Foliar application of nano-fertilizers also calls into focus efficient spray application technologies with agritech solutions such as through UAVs / drones, electrostatics prayers besides conventional sprayers. Nanofertilizers 
suitable for application through drip, seed priming / treatment and soil application also needs to be developed for farmers convenience of application. Nanotechnology-based solutions have more relevance for countries like India where resource conservation has to be seen in the light of increase in population next only to China.

Nano-fertilizers should therefore be viewed in totality as an option to address the challenges being faced by modern day intensive agriculture. It is high time that the nano-fertilizers are accepted as an 'informed choice' to address

\section{REFERENCES}

Ashrafi, S.J., Rastegar, M.F., Jafarpour, B. and Kumar, S.A. (2010) Possibility use of silvernano particle for controlling Fusarium wilting in plant pathology. In: Riberio $\mathrm{C}$, deAssis OBG, Mattoso LHC, Mascarenas S (eds) Symposium of international conference on food and agricultural applications of nanotechnologies, São Pedro SP, Brazil. ISBN 978-85-63274-02-4

Atha ,D.H, Wang, H., Petersen, E.J., Cleveland, D., Holbrook, R.D., Jaruga, P, Dizdaroglu, M., Xing, B., and Nelson, B. C.(2012)Copper oxide nanoparticle-mediated DNA damage in terrestrial plant models. Environmental Science and Technology46:1819-1827

Brennan, B. (2012) Nano biotechnology in agriculture. Strategic business insights 2012, Menlo Park, CA, USA, Available from:http://www.strategicbusinessinsights. com/about/featured/2012/2012-10-nanobioagriculture.shtml.

Cakmak, I. (2000) Role of zinc in protecting plant cells from reactive oxygen species. New Phytologist 146:185-205.

DeRosa, M.C., Monreal, C., Schnitzer, M., Walsh, R. and Sultan, Y. (2010) Nanotechnology in fertilizers. Nature Nanotechnology 5:91-94.

Dimkpa, C.O., Latta, D.E., McLean, J.E., Britt, D. W., Boyanov, M.I. and Anderson, A. J. (2013) Fate of $\mathrm{CuO}$ and $\mathrm{ZnO}$ nano and micro particles in the plant environment. Environmental Science \&Technology 47:4734-4742

Dimkpa, C.O., McLean, J.E., Latta, D.E., Manangón, E., Britt, D.W., Johnson, W.P., Boyanov, M.I. and Anderson, A.J. (2012) persistent limitations affecting sustainability and profitability of our agriculture.

\section{ACKNOWLEDGEMENT}

The contribution of research scientists, KVK's, progressive farmers, IFFCO field officers who have been engaged in IFFCO Nano research experimental trialsis duly acknowledged. We express our gratitude to different open access resource providers, individuals and internet knowledge portals.

$\mathrm{CuO}$ and $\mathrm{ZnO}$ nano particles: phytotoxicity, metal speciation and induction of oxidative stress in sand-grown wheat. Journal of Nanoparticle Research14:1125

Dwairi, J.M. (1998) Renewable, controlled and environmentally safe phosphorous released in soil mixtures of $\mathrm{NH}+-$ phillip sitetuff and phosphate rock. Environmental Geology 34:293-296

Dwivedi, R.S. and Randhawa, N.S. (1974) Evaluation of a rapid test for hidden hunger of $\mathrm{Zn}$ in plants. Plant \& Soil 40:445-451

Gao, F., Hong, F., Liu, C., Zheng, L., Su, M., Wu, X., Yang F, Wu C, and Yang P (2008) Mechanism of nano-anatase $\mathrm{TiO} 2$ on promoting photosynthetic carbon reaction of spinach. Biological Trace Element Research 111:239-253

Hafeez, A., Razzaq, A, Mahmood, T, and Jhanzab H.M. (2015) Potential of copper Nanoparticles to increase growth and yield of wheat. Journal of Nanoscience with Advanced Technology 1(1):6-11

Hernandez G, Diaz R, Notariodel Pino J.S., and Gonzalez Martin M.M. (1994) NH+ Naexchangeand $\mathrm{NH}+$ release studies in natural phillip site. Applied Clay Science9:29-137

Husen A, Siddiqi K.S, (2014) Carbon and fullerene nano materials in plant system. J Nanotechnol 12:1-10

Khodakovskaya $M$, Dervishi $E$, Mahmood $M$, XuY, LiZ, Watanabe F, and Biris A.S. (2009) Carbon nanotubes are able to penetrate plant seed coat and dramatically affect seed germination and plant growth. American Chemical Society Nano3:3221-3227 
Khodakovskaya, M.V., deSilva, K., Biris,A. S., Dervishi, E, and Villagarcia, H. (2012) Carbonna no tubes induce grow the enhancement of tobacco cells. American Chemical Society Nano 6:2128-2135

Kisan, B., Shruthi, H., Sharanagouda, H., Revanappa, S. B. and Pramod N.K.(2015) Effect of nano-zinc oxide on the leaf physical and nutritional quality of spinach. Agro technology 5:135. doi:10. 4172/21689881.1000135

Klaine, S.J., Alvarez, P.J.J., Batley, G.E, Fernandes, T.F. Handy, R.D.Lyon, D.Y., Mahendra, S., McLaughlin, M. L. and Lead JR (2008) Nanomaterials in the environment: behaviour, fate, bio availability, and effects. Environmental Toxicology and Chemistry27:1825-1851

Kottegoda, N., Munaweera, I., Madusanka, N., and Karunaratne,V. (2011) A green slowrelease fertilizer composition based on ureamodified hydroxyapatite nanoparticles encapsulated wood. Current Science 101(1):73-78

Kumari, M., Khan, S.S., Pakrashi, S., Mukherjee, A, and Chandrasekaran, N. (2011) Cytogenetic and genotoxic effects of zinc oxide nanoparticles on root cells of Allium cepa. Journal of Hazardous Materials 190:613

Laware, S. L., and Raskar, S. (2014) Influence of zincoxide Nanoparticles on growth, flowering and seed productivity in onion. International Journal of Current Microbiology and Applied Sciences 3(7):874-881

Lee,W. M., AN, Y. J., Yoon, H, and Kwbon, H.S. (2008) Toxicity and bioavailability of copper nanoparticles to the terrestrial plants mungbean (Phaseolus radiatus) and wheat (Triticuma estivum):plant agartest for waterinsoluble nanoparticles. Environmental Toxicology and Chemistry27:1915-1921

LinD, Xing B. (2007) Phyto toxicity of Nanoparticles: Inhibition of seed germination and root growth. Environmental Pollution150:243-250

LinS, Reppert J., HuQ, Hudson J.S., Reid ML, Ratnikova T.A, Rao A.M., Luo H., and KeP.C. (2009) Uptake, translocation, and transmission of carbon nanomaterials in rice plants.Small 5: 1128-1132

López-Moreno, M.L, dela Rosa, G., HernándezViezcas, J.A., Peralta-Videa, J.R., and
Gardea-Torresdey, J.L. (2010P) AS corroboration of the uptake and storage of $\mathrm{CeO} 2$ nanoparticles and assessment of their different altoxicity in foure dibble plantspecies. Journal of Agricultural and Food Chemistry 58(6):3689-3693

Mahajan P, Dhoke S.K., Khanna A.S., Tarafdar J.C. (2011) Effect of nano-ZnO on growth of Mung Bean (Vigna radiata) and Chickpea (Cicer arietinum) seedlings using plant agar method. Appl Biol Res 13:54-61

Manikandan and Subramanian, K.S. (2014) Fabrication and characterization of nanoporouszeolite based $\mathrm{N}$ fertilizer. African Journal of Agricultural Research 9(2):276284

Millán, G., Agosto, F.,Vázquez, M., BottoL., Lombardi, L.and Juan, L. (2008)Use of clinoptilolite as a carrier for nitrogen fertilizers in sois of the Pampean regions of Argentina. Cienciae Investigation Agraria35:245-254.

Naderi,M. R. and Abedi A. (2012) Application of nanotechnology in agriculture and refinement of environmental pollutants. Journal of Nanotechnology 11(1):18-26.

Naderi, M. R. and Danesh-Shahraki, A. (2013) Nanofertilizers and their roles in sustainable agriculture International Journal of Agriculture and Crop Sciences 5(19):22292232.

Nair, R., Mohamed, M.S., Gao, W., Maekawa, T., Yoshida, Y., Ajayan, P.M. and Kumar , D.S. (2012) Effect of carbon nanomaterials on the germination and growth of rice plants. Journal of Nano science and Nano technology12 (3):2212-2220.

Nair, R., Varghese, S. H., Nair, B. G., Maekawa, T., Yoshida, Y. and Kumar DS (2010) Nanoparticulate material delivery to plants. Plant Science 179:154-163

Nanotechnology in Agriculture and Food (2006) Europe an nanotechnology gateway. http://www.nanoforum.org/dateien/temp/nano technology\%20in\%20agriculture\%20-and\% 20 food.pdf

Panwar, J. Jain, N., Bhargaya, A., Akthar, M. and Yun, Y.S. (2012) Positive effect of zinc oxide nanoparticles on tomato plants: a step towards developing "nano-fertilizers". In: 3rd International Conference on Environmental Research and Technology, pp3 48-352

Pérez-de-Luque,A, and Hermosín, M.C. (2013) Nanotechnology and its use in agriculture. 
In:Bagchi D, Bagchi M, Moriyama $H$, Shahidi F(eds) Bio-nanotechnology: are volution in food, biomedical and health sciences. WileyBlackwell, West Sussex, pp 299-405

Perrin, T. S., Drost, D. T, Boettinger, J.L. and Norton JM (1998) Ammonium-loaded clinoptilolite: a slow-release nitrogen fertilizer for sweet corn. Journal of Plant Nutrition 21:515-530

Pramod Mahajan, S. K. Dhoke, A. S. Khanna, "Effect of Nano-ZnO Particle Suspension on Growth of Mung (Vigna radiata) and Gram (Cicer arietinum) Seedlings Using Plant Agar Method", Journal of Nanotechnology, Vol. 2011, Article ID 696535, 7 pages, 2011. https://doi.org/10.1155/2011/696535

Prasad, T. N. V. K. V., Sudhakar, P., Sreenivasulu, Y., Latha, P., Munaswamy, V., Reddy, K. R., Sreeprasad, T. S..P., Sajanlal, R. and Pradeep, T. (2012) Effect of nanoscale zinc oxide particles on the germination, growth and yield of peanut. Journal of Plant Nutrition 35(6):905-927

Prasad, R. (2013) "Fertilizer Nitrogen, Food Security, Health and the Environment. Proceedings Indian National Science Academy 79 No. 4. Spl. Issue, Part B, 9971010

Priestera,,J. H, Gea Y, Mielkea R.E., Horsta A.M., Moritzb S.C., Espinosae K., Gelbf J, Walkerg S.L., Nisbetb R.M., Ani Y.J., Schimelb J.P., Palmere R.G., HernandezViezcasc J.A., Zhaoc L., Gardea-Torresdey J.L. and Holdena, P.A. (2012) Soybean susceptibility to manufactured nano materials with evidence for food quality and oil fertility interruption. Proceedings of National Academy of Sciences USA 109:1473414735

Rahale, C.S. (2010) Nutrient lease pattern of nano-fertilizer formulations. PhD Thesis, Tamil Nadu Agricultural University, Coimbatore, Tamil Nadu, India

Raliya R,. and Tarafdar, J. C. (2013)ZnO nanoparticle biosynthesis and its effect on phosphorous- mobilizingen zymesecretion and gum contents in clusterbean (Cyamopsiste tragonolobaL.). Agricultural Research 2 (1):48-57

Raliya, R. Tarafdar, J. C. K. Gulecha, Choudhary, K. Rameshwar Ram, Prakash Mal and Saran, R. P. (2013). Review Article; Scope of Nanoscience and Nanotechnology in Agriculture. Journal of Applied Biology and Biotechnology, 1 (03): 041-044.

Razzaq A .Ammara, R., Jhanzab, H. M., Mahmood, T., Hafeez, A. and Hussain S (2016) Anovel nano material toenhance growth and yield of wheat. Journal of Nanoscience and Nanotechnology 2(1):5558

Rico, C. M, Majumdar S, Duarte-Gardea M, Peralta-Videa JR, and Gardea-Torresdey JL (2011) Interaction of Nanoparticles with edible plants and their possible implications in the food chain. Journal of Agricultural and Food Chemistry 59:3485-3498

Saigusa, M. (2000) Broad cast applications were suspend application of polyolefin-coated fertilizer on green peppers grown on Andisol. Journal of PlantNutrition 23:1485-1493

Sekhon, B. S. (2014) Nanotechnology in agrifood production: an over view. Nanotechnology, science and applications 7:31-53

Serag, M. F., Kaji, N., Tokeshi, M. and Baba Y. (2012a) Introducing carbon nano tubes in toliving walled plant cells through cellulaseinduced nanoholes. Royal Society of Chemistry Advances 2:398-400

Serag, M.F.,Kaji, N., Venturelli, E., Okamoto, Y., Terasaka, K., Tokeshi, M., Mizukami, H., Ugent, K. B. and Bianco, Baba, Y. (2011b) Trafficking and subcellular localization of multiwalled carbon nanotubes in plant cells. American Chemical Society Nano 5:493-499

Shankar, S. S., Ahmad A., and Sastry, M. (2003) Geranium leaf as sisted bio synthesis of silver nano particles. Biotechnology Progress19 (6):1627-31.

Sharma, V., Shukla, R, K., Saxena M., Parmar D., Das, M. and Dhawan, A. (2009) DNA damaging potential of $\mathrm{ZnO}$ nano particles in human epidermal cells. Toxicology letters 185(3):211-218.

Shyla, K.K. and Natarajan, N (2014) Customising zin coxide, silver and titaniumdi oxide nano particles for enhancing groundnut seed quality. Indian Journal of Science and Technology 7 (9):1376-1381.

Solanki, P., Bhargava, A., Chhipa, H.,Jain, N. and Panwar,J. (2015) Nano-fertilizers and their smart delivery system. In: Rai M,Ribeiro C,Mattoso L, Duran N(eds) Nanotechnologies in food and agriculture. Springer, Switzerland, pp81-101. 
Sonkaria, S., Ahn, S. H. andKhare, V. (2012) Nanotechnology and it simpacton food and nutrition: a review. Recent patents on Food, Nutrition \& Agriculture $4(1): 8-18$.

Sooyeon, L., Sunghyun, K., and Saeyeon, K. Insook, L. (2013) Assessment of phytotoxicity of ZnO NPs on medicinal plant Fagupyrumesculentum. Environmental Science and Pollution Research International 20:848-854.

Stampoulis, D., Sinha, S.K, and White, J.C. (2009) As say dependentphy to toxicity of nanoparticles to plants. Environmental Science \& Technology 43:9473-9479.

Stella, W.Y.W., Priscilla, T.Y. L., Djurisi,A. B., and Kenneth, M.Y.L. (2010) Toxicities of nano zincoxide to five marine organisms: influences of aggregate zinc size and on solubility. Analytical and Bioanalytical Chemistry 396(2):609-618.

Subramanian, K.S. and Rahale, C.S. (2009) Synthesis of nanofertiliser formulations for balanced nutrition. In: Proceedings of the Indian society of Soil Science-Platinum Jubilee Celebration, December 22-25, IARI, New Delhi, India, pp85.

Sugunan, A. and Dutta, J. (2008) Pollution treatment, remediation and sensing. In: Harald K (ed) Nanotechnology, vol 3. WileyVCH, Weinheim, pp 125-143.

Sultan,Y., Walsh, R.,Monreal, C.M., and DeRosa, M.C. (2009) Preparation of functional aptamer films using layer-by-layer self-assembly. International journal of biological macromolecules 10:1149-1154.

Torney F, Trewyn B.G, L in VS, and Wang, K (2007) Mesoporoussilica nano particles deliver DNA and chemicals into plants. Nature Nanotechnology 2:295-300.

Trenkel, M.E. (2010) Slow-and controlledrelease and stabilized fertilizers: an option for enhancing nutrient use efficiency in agriculture. International Fertilizer Industry Association, Paris, France, pp1-162.

Villagarcia, H., Dervishi, E., Silva, K., Biris, A. S. and Khodakovskaya M.V. (2012) Surface chemistry of carbon nano tubes impacts the growth and expression of water channel protein in tomato plants. Small 8:2328-2334.

Wang, J., Koo, Y., Alexander, A., Yang, Y., Westerhof, S., Zhang, Q.B., Schnoor, J.
L.,Colvin,V. L., Braam, J., and Alvarez, P. J. J. (2013a) Phytostimulation of poplars and Arabidopsis exposed to silver nano particles and $\mathrm{Ag}+$ at sublethal concentrations. Environmental Science \& Technology 47:5442-5449.

Wang, P., Menzies, N. W., Lomb,i E., McKenna, B. A., Johannessen, B., Glover, C. J., Kappen, P. and Kopittke, P.M.(2013b) Fate of $\mathrm{ZnO}$ Nanoparticles in soils and Cowpea (Vignaunguiculata). Environmental Science \& Technology47:13822-13830.

Wang Q, Ebbs S.D., Chen,Y., and MaX .( 2013c) Trans-generational impact of ceriumoxide nano particles on tomato plants. Metallomics5 (6):753-759.

Welch, R.M, Webb, M.J., Loneragan, J.F. (1982) Zinc in membrane function and its role in phosphorus toxicity. In: Scaife A (ed) Proceedings of the ninth plant nutrition colloquium. $\mathrm{CAB}$ International, Wallingford, UK, pp710-715.

Yogendra Kumar, Tiwari, K.N. Nayak, R.K. Abhimanyu Rai, Singh, S.P. Singh, A.N., Yatendra Kumar, Harish Tomar, Tarunendu Singh and Ramesh raliya (2020) "Nano fertilizers for enhancing nutrient use efficiency, crop productivity and economic returns in winter season crops of Uttar Pradesh "Indian Journal of Fertilisers 16 (8) : 772-786.

Yogendra Kumar, Tiwari, K.N. Tarunendusingh, Naveen Kumar Sain, Sri Laxmi, Ramesh Verma, Girish Chandra Sharma and Ramesh Raliya (2020), "Nanofertilizers for enhancing nutrient use efficiency, crop productivity and economic returns in winter season crops of Rajasthan. Annals of Plant and Soil Research, 22(4): 324-335.

Zheng, L., Hong, F. S., Lu, S. P. and Liu, C. (2005) Effect of nano-TiO2 on strength of naturally and growth aged seeds of spinach. Biological Trace Element Research104: 8391.

Zhu, H, Han, J., Xiao, J.Q., Jin, Y. (2008) Uptake, translocation, and accumulate on of manufactured iron oxide nano particles by pumpkin plants. Journal of Environmental Monitoring10:713-717. 